\title{
What is being measured with P-bearing NMR probe molecules adsorbed on zeolites?
}

\author{
Carlos Bornes, ${ }^{a}$ Michael Fischer, ${ }^{\mathrm{b}}$ Jeffrey A. Amelse, ${ }^{\mathrm{a}}$ Carlos F. G. C. Geraldes, ${ }^{\mathrm{c}}$ João Rocha ${ }^{\mathrm{a}}$ and Luís \\ Mafra*a \\ a CICECO, Aveiro Institute of Materials, Department of Chemistry, University of Aveiro, 3810-193 Aveiro, Portugal. \\ b Faculty of Geosciences, University of Bremen, 28359 Bremen, Germany; MAPEX Center for Materials and Processes, \\ University of Bremen, 28359 Bremen, Germany. \\ ${ }^{\mathrm{c}}$ Department of Life Sciences and Coimbra Chemistry Center, Faculty of Science and Technology, University of \\ Coimbra, 3000-393 Coimbra, Portugal; CIBIT-Coimbra Institute for Biomedical Imaging and Translational Research, \\ Edifício do ICNAS, 3000-548 Coimbra, Portugal.
}

\section{MATERIALS AND METHODS}

\section{Materials preparation}

HZSM-5 zeolite samples were prepared from $\mathrm{NH}_{4} \mathrm{ZSM}-5$ zeolite obtained from Zeolyst International (ref. CBV3024E) by calcining $2.5 \mathrm{~g}$ of the initial material under $5 \mathrm{~L} / \mathrm{h}$ air flow at $500{ }^{\circ} \mathrm{C}$. In order to avoid the formation of large amounts of EFAL species, a two-steps calcination procedure was used, ramping from room temperature to $200{ }^{\circ} \mathrm{C}$ at $5^{\circ} \mathrm{C} / \mathrm{min}$, keeping at 200 ${ }^{\circ} \mathrm{C}$ for 2 hour, and then ramping to $500{ }^{\circ} \mathrm{C}$ at $5{ }^{\circ} \mathrm{C} / \mathrm{min}$, and holding for 6 h. The prepared HZSM-5 samples were kept closed in a desiccator containing a saturated aqueous solution of magnesium nitrate ( $54.4 \%$ relative humidity at $\left.20{ }^{\circ} \mathrm{C}\right)$ until being used.

\section{TMPO adsorption}

TMPO-loaded HZSM-5 samples were prepared by packing $50 \mathrm{mg}$ of hydrated HZSM-5 zeolite into a 4 mm NMR rotor, followed by dehydration under high-vacuum $\left(10^{-5} \mathrm{mbar}\right)$ at $300{ }^{\circ} \mathrm{C}$ for 4 hours. The sample was dehydrated in a specially designed vacuum cell that allows heating the NMR rotor containing the sample and closing it under helium. The closed NMR rotor was then transferred to an Argon-filled glove box, with $\mathrm{H}_{2} \mathrm{O}$ and $\mathrm{O}_{2}$ levels below 1 ppm. Around 1, 2 and 4 mg of TMPO were added to the dehydrated zeolite samples and the rotors resealed under inert and dry atmosphere. 0-ring containing NMR caps were used as they ease the process of opening and closing the rotor inside the glove box. The NMR rotors were then transferred again to the dehydration cell and heated at $150{ }^{\circ} \mathrm{C}$ for 4 hours. All samples were spun at the magic angle prior to the dehydration and adsorption steps, resulting in a vortex passing through the middle of the packed sample, allowing better diffusion of water and sublimated TMPO during the dehydration and adsorption steps, respectively. Phosphorous to aluminum $(\mathrm{P} / \mathrm{Al})$ ratios were calculated using the weight of zeolite and TMPO inside each NMR rotor. We have considered a unit cell $\mathrm{H}_{5.3} \mathrm{Si}_{90.6} \mathrm{Al}_{5.3} \mathrm{O}_{192}(\mathrm{Si} / \mathrm{Al}=18)$ and a mass loss of $7 \%$, as shown in a previous work. ${ }^{1}$

\section{NMR spectroscopy}

${ }^{31} \mathrm{P}$ and ${ }^{1} \mathrm{H}$ NMR spectra were acquired on a Bruker Avance III 400 spectrometer operating at a $\mathrm{B}_{0}$ field of $9.4 \mathrm{~T}$, at ${ }^{31} \mathrm{P}$ and ${ }^{1} \mathrm{H}$ Larmor frequencies of 161.9 and $400.1 \mathrm{MHz}$, respectively, on a $4 \mathrm{~mm}$ Bruker MAS probe. The samples were packed into 4 $\mathrm{mm} \mathrm{ZrO}_{2}$ rotors with $4 \mathrm{~mm}$ o-ring Macor caps. Chemical shifts are quoted in ppm from TMS using the following secondary references: solid adamantane $(1.85 \mathrm{ppm})$ and solid $\mathrm{Na}_{4} \mathrm{P}_{2} \mathrm{O}_{7}\left(-2.09 \mathrm{ppm}\right.$ for the most shielded resonance) for ${ }^{1} \mathrm{H}$ and ${ }^{31} \mathrm{P}$, respectively. ${ }^{1} \mathrm{H}$-decoupled ${ }^{31} \mathrm{P}$ MAS NMR spectra were acquired at a spinning rate of $15 \mathrm{kHz}$ using a $3.2 \mu$ pulse $\left(90^{\circ}\right.$ flip angle) corresponding to a radiofrequency (rf) field strength of $78 \mathrm{kHz}$. A recycle delay (RD) of $20 \mathrm{~s}$ was used. ${ }^{1} \mathrm{H}-{ }^{31} \mathrm{P}$ HETCOR NMR spectra were acquired using a ${ }^{1} \mathrm{H} 2.8 \mu$ s pulse width $\left(90^{\circ}\right.$ flip angle) corresponding to a $\mathrm{rf}$ of $90 \mathrm{kHz}$, the crosspolarization step was performed using a contact time of $3500 \mu$ s with a 70-100\% RAMP shape on the ${ }^{1} \mathrm{H}$ channel and a square shaped pulse of $51 \mathrm{kHz}$ on the ${ }^{31} \mathrm{P}$ channel, a RD of $2.25 \mathrm{~s}$ and a spinning rate of $15 \mathrm{kHz}$. A SPINAL-64 decoupling scheme was used with pulse length of $6 \mu \mathrm{s}$ at a rf field strength of $80 \mathrm{kHz} .145 \mathrm{t} 1$ points with 2048 scans each were recorded along the indirect dimension. The simulation of the ${ }^{31} \mathrm{P}$ NMR spectra was carried out using Gaussian/Lorentzian curves as implemented in the DMFIT software. ${ }^{2}$

\section{Computational modeling}

Periodic HZSM-5 models were constructed by adding one aluminum atom and the corresponding $\mathrm{H}^{+}$counterion at the i) intersection of sinusoidal and straight channels, ii) 10 membered-ring (10MR) straight channels, and iii) $10 \mathrm{MR}$ straight channels, to an all-silica MFI structure available at IZA's database. ${ }^{3}$ The models used to calculate the interaction of TMPO with Brønsted acid sites had the balancing protons pointing towards the middle of the straight and sinusoidal channels and channel 
intersections. Calculations were performed using $1 \times 1 \times 2$ and $2 \times 1 \times 1$ supercells for acid sites located at the channel intersection and the sinusoidal channel, respectively. Supercells were used to account for all significant zeolite-guest interactions, leading to the stabilization of 1:1 and 2:1 TMPO complexes and reducing the artificial interactions between periodic images of TMPO. The initial structures of TMPO-loaded HZSM-5 zeolites were generated by adapting the procedure of Drout et al., using the MBAI tool. ${ }^{4}$ MBAI allows placing the TMPO molecules at an acceptable site using classical molecular mechanics and Monte Carlo (MC) algorithms, as implemented in the RASPA code. ${ }^{5}$ This procedure avoids the laborious and error-prone work of placing the guest-molecules manually. The TMPO molecules were placed at around $1.5 \AA$ Arom the Brønsted acid site proton and, in the case of 2:1 complexes, at around $1.5 \AA$ from the proton at the protonated TMPOH ${ }^{+}$. Error! Reference source not found. depicts the computational approaches used here to model the formation and to compute the NMR parameters of $1: 1$ (1 TMPO per acid site) and 2:1 complexes (2 TMPO per acid site).

DFT structure optimizations and DFT-based AIMD simulations were carried out with the CP2K code (version 7.1 installed on HLRN-IV), which uses a hybrid Gaussian and plane wave approach. ${ }^{6,7}$ These calculations used the PBE exchangecorrelation functional ${ }^{8}$ and the "Grimme-type" D3 dispersion correction. ${ }^{9}$ This functional has been successfully employed in a previous benchmarking work of all-silica zeolites, ${ }^{10}$ and in AIMD studies of fluoride-containing zeolites. ${ }^{11,12}$ The CP2K calculations used a plane wave energy cutoff of 600 Ry, Goedecker-Teter-Hutter pseudopotentials devised by Krack, ${ }^{13}$ triplezeta Gaussian basis sets (TZVP-MOLOPT-GTH) for optimizations, and double-zeta (DZVP-MOLOPT-SR-GTH) Gaussian basis sets for AIMD simulations. ${ }^{14}$ Due to the size of the MFI unit cell, only the $\Gamma$ point was used to sample the first Brillouin zone.

The structure optimizations used a BFGS optimization method, optimizing all atomic positions, but fixing the unit cell parameters to $a=20.022 \AA, b=19.899 \AA, c=13.142 \AA .{ }^{15}$ Calculations were considered to have converged when the magnitude of the geometry change from one step to the next was below $5 \times 10^{-5}$ Bohr and when the maximal residual force was smaller than $5 \times 10^{-6} \mathrm{Ha} \mathrm{Bohr}^{-1}$.

AIMD simulations were performed in the NVT (canonical) ensemble $423 \mathrm{~K}$, mimicking the experimental conditions for the adsorption of TMPO. The calculations employed a Nosé-Hoover thermostat with a time step of 0.5 fs and a time constant of 50 fs. Trajectories for 2:1 complexes were calculated for a total simulation time of 2.5 ps (5000 steps). The AIMD step was used to enhance the sampling of the local minima, compared to the conventional DFT-based geometry optimization approach. The final structures obtained from AIMD trajectories were extracted and converged with the procedure detailed above. While the structure of 2:1 complexes and their calculated NMR parameters change significantly between the DFT and AIMD calculations, for 1:1 complexes the obtained results are identical for both methods.

NMR chemical shifts were calculated using HZSM-5 cluster models containing 40 tetrahedral atoms (Si and Al) constructed from the optimized periodic models. The terminal oxygen atoms of these $40 \mathrm{~T}$ clusters were replaced by hydrogen atoms. ${ }^{1} \mathrm{H}$ and ${ }^{31} \mathrm{P}$ NMR chemical shieldings were calculated using the gauge-independent atomic orbital (GIAO), ${ }^{16}$ and the PBE1PBE/6$311 \mathrm{~g}(2 \mathrm{~d}, 2 \mathrm{p})$ basis set as implemented in Gaussian 16 revision C.01. ${ }^{17}$ This basis set is a reliable basis set to calculate ${ }^{31} \mathrm{P}$ chemical shifts, at a reasonable cost. ${ }^{18}{ }^{1} \mathrm{H}$ and ${ }^{31} \mathrm{P}$ NMR chemical shifts were calculated using the following formula, $\delta=\sigma_{r e f}-$ $\sigma+\delta_{\text {ref }}$, where $\sigma$ and $\sigma_{\text {ref }}$ are the chemical shieldings calculated at the same theoretical level, $\delta_{\text {ref }}$ the reference experimental chemical shift $\left({ }^{1} \mathrm{H}: \alpha\right.$-glycine's $\mathrm{CH}_{2}$ group, $3.5 \mathrm{ppm}$ and ${ }^{31} \mathrm{P}$ : TMPO, $\left.41 \mathrm{ppm}\right)$. 


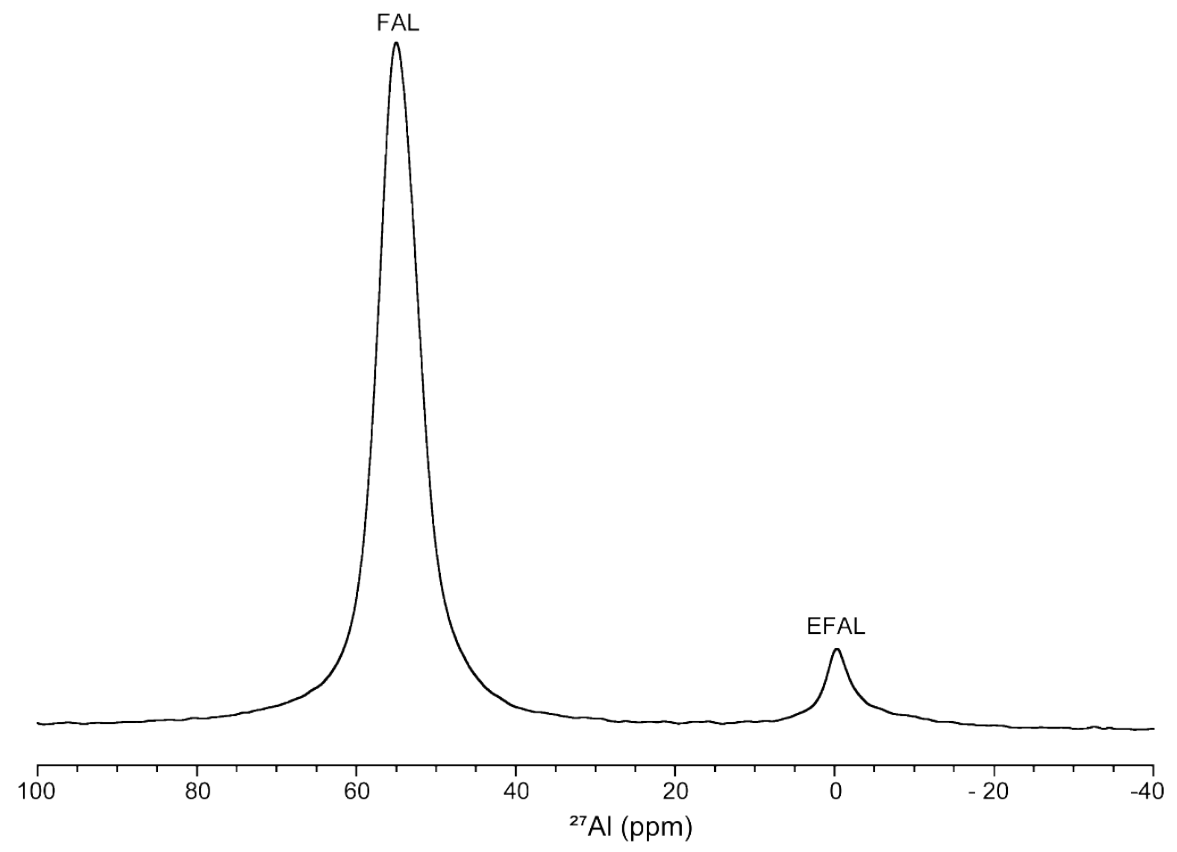

Figure S1. ${ }^{27} \mathrm{Al}$ MAS NMR spectrum of the commercial HZSM-5 zeolite used in this work (Zeolyst ref. CBV 3024E). FAL and EFAL denote framework and extraframework aluminum atoms, respectively.

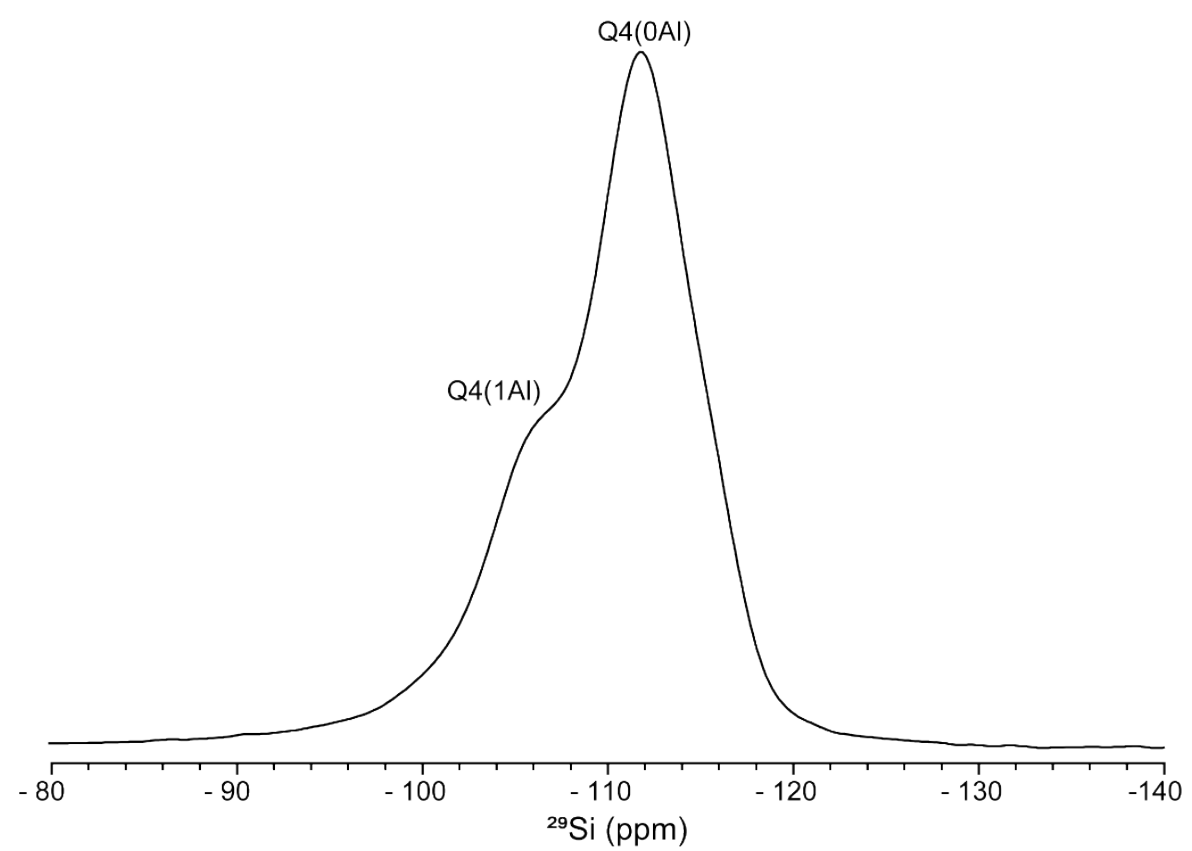

Figure S2. ${ }^{29} \mathrm{Si}$ MAS NMR spectrum of the commercial HZSM-5 zeolite used in this work (Zeolyst ref. CBV 3024E). $\mathrm{Q}^{4}(0 \mathrm{Al})$ denotes Si atoms with $4 \mathrm{Si}$ next-nearest atoms, and $\mathrm{Q}^{4}(1 \mathrm{Al}) \mathrm{Si}$ atoms with $3 \mathrm{Si}$ and $1 \mathrm{Al}$ next-nearest atoms. 


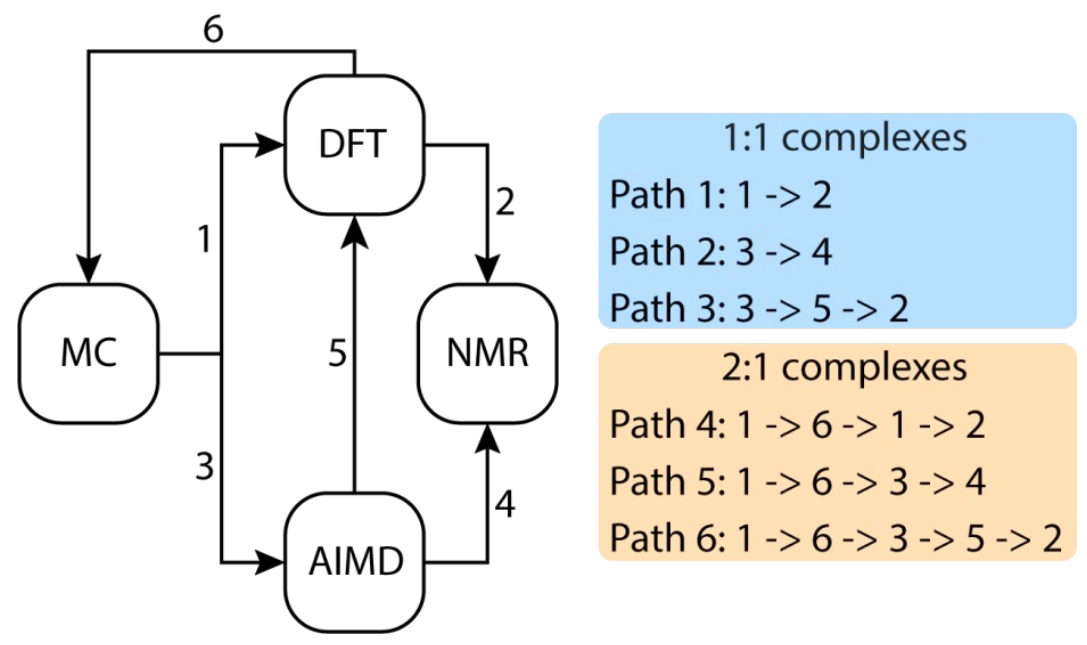

Figure S3. Computational approaches used in this work, 1:1 complexes were modelled using: Path 1) MC $\rightarrow$ DFT $\rightarrow$ NMR, Path 2) MC $\rightarrow$ AIMD $\rightarrow$ NMR, Path 3) MC $\rightarrow$ AIMD $\rightarrow$ DFT $\rightarrow$ NMR and 2:1 complexes using: Path 4) MC $\rightarrow$ DFT $\rightarrow$ MC $\rightarrow$ DFT $\rightarrow$ NMR, Path 5) $\mathrm{MC} \rightarrow \mathrm{DFT} \rightarrow \mathrm{MC} \rightarrow \mathrm{AIMD} \rightarrow \mathrm{NMR}$ and Path 6) $\mathrm{MC} \rightarrow \mathrm{DFT} \rightarrow \mathrm{MC} \rightarrow \mathrm{AIMD} \rightarrow \mathrm{DFT} \rightarrow \mathrm{NMR}$.

A

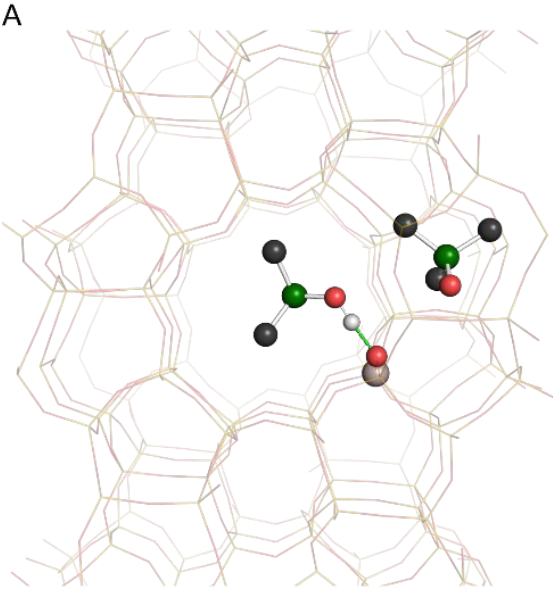

B

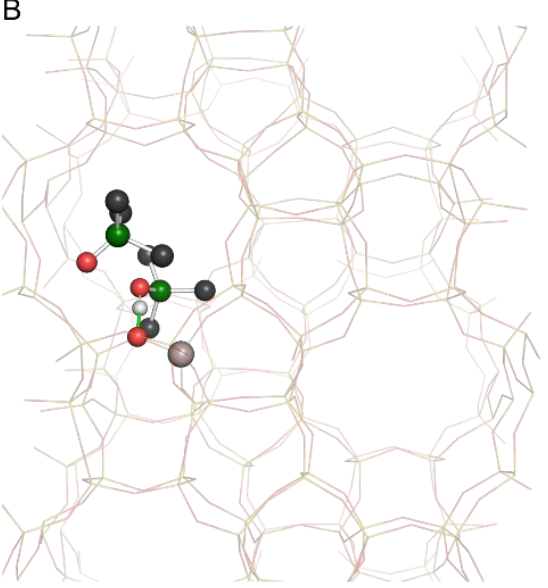

C

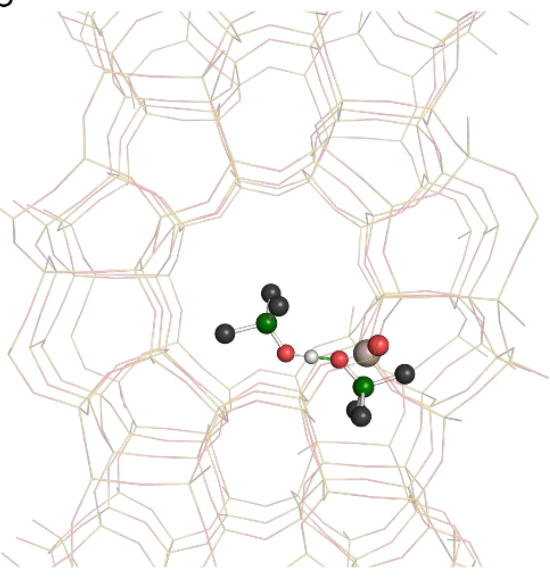

D

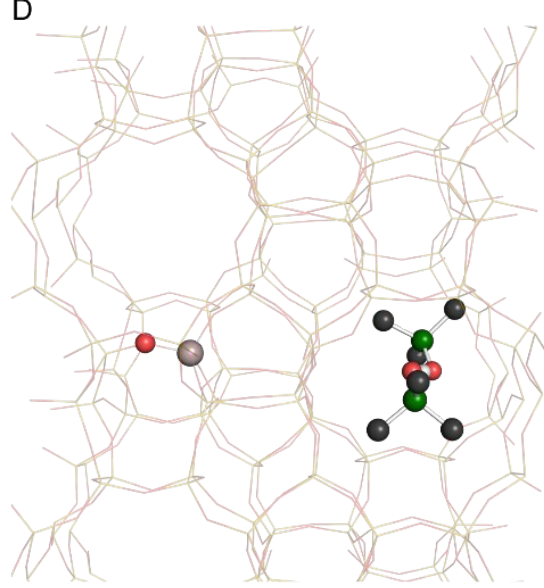

$O H \odot \mathrm{CH}_{3} \odot \mathrm{O} \odot \mathrm{Si} \odot \mathrm{Al} \odot \mathrm{P}$

Figure S4. HZSM-5 zeolite framework viewed along the crystallographic b-axis (A and C) and a-axis (B and D). DFT-based geometry optimized TMPO:Brønsted acid 2:1 models showing a $\mathrm{TMPOH}^{+}$ion and a free TMPO molecule at the channel intersection (A and B). Models showing (TMPO) ${ }_{2} \mathrm{H}^{+}$dimer in pure-silica channel intersection, i.e., without framework Al sites, are also depicted (C and D). Calculated ${ }^{1} \mathrm{H}$ and ${ }^{31} \mathrm{P}$ NMR chemical shifts and interatomic distances are given in Tables S3 and S4. 
A)

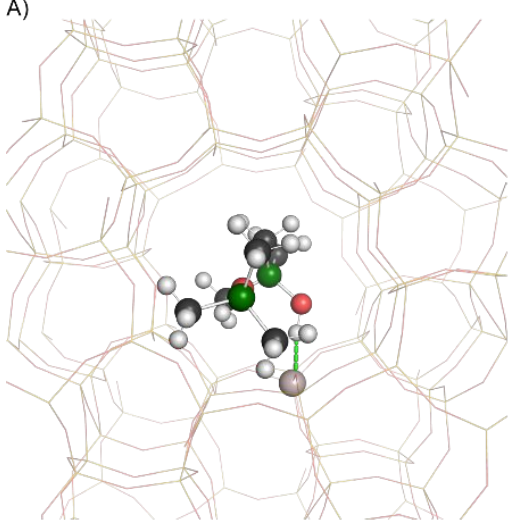

B)

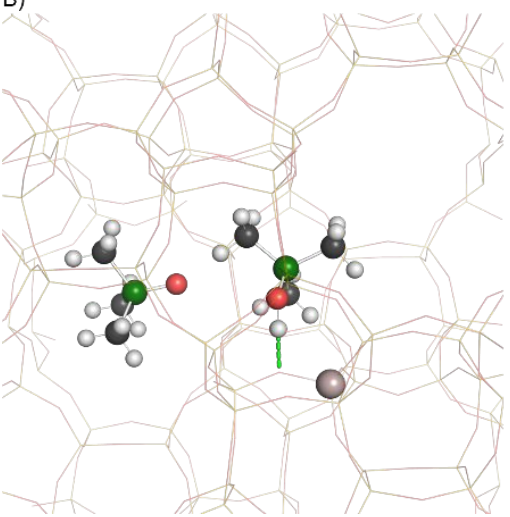

C)

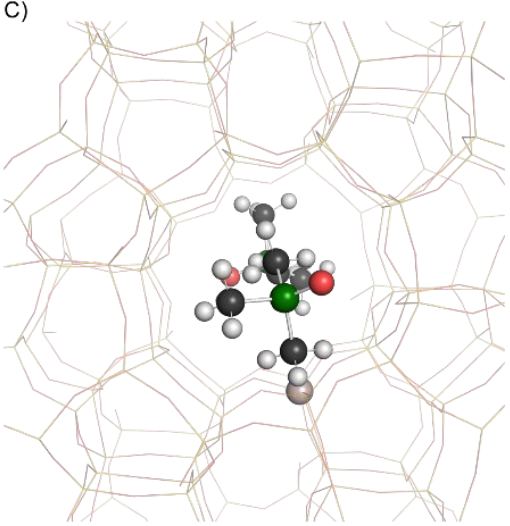

D)

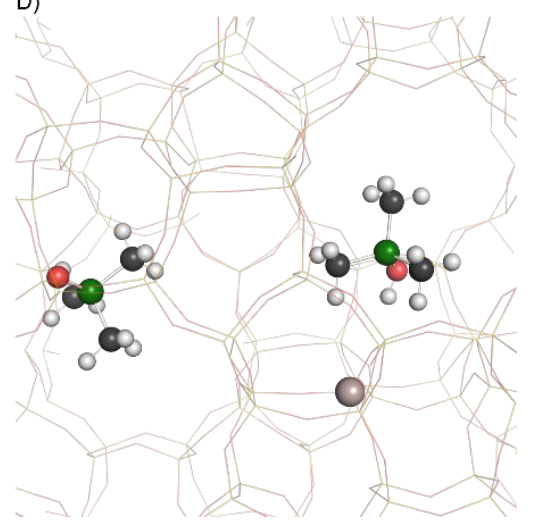

Figure S5. HZSM-5 zeolite framework viewed along the crystallographic b-axis (A and C) and a-axis (B and D). DFT (A, B) and AIMD followed DFT (C, D) geometry optimized TMPO:Brønsted acid 2:1 models at the 10MR straight channels showing a TMPOH ${ }^{+}$ion and a free TMPO molecule. Calculated ${ }^{1} \mathrm{H}$ and ${ }^{31} \mathrm{P}$ chemical shifts and interatomic distances are given in Table $\mathrm{S} 9$. 
A)

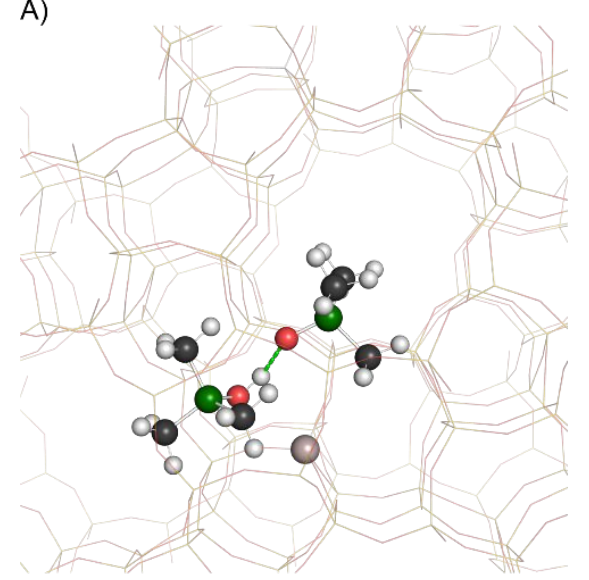

B)

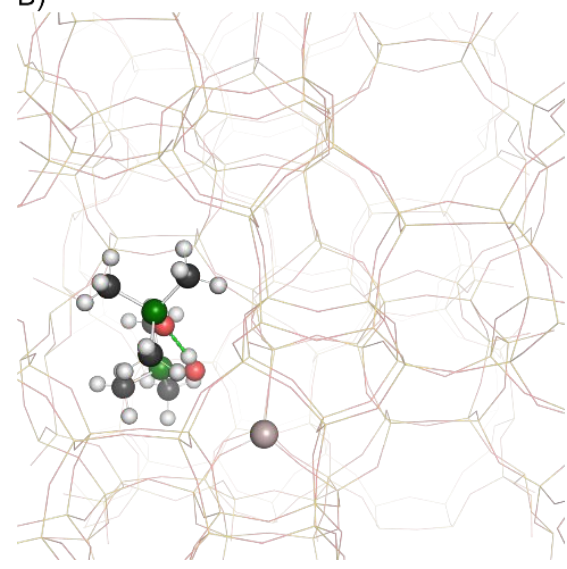

C)

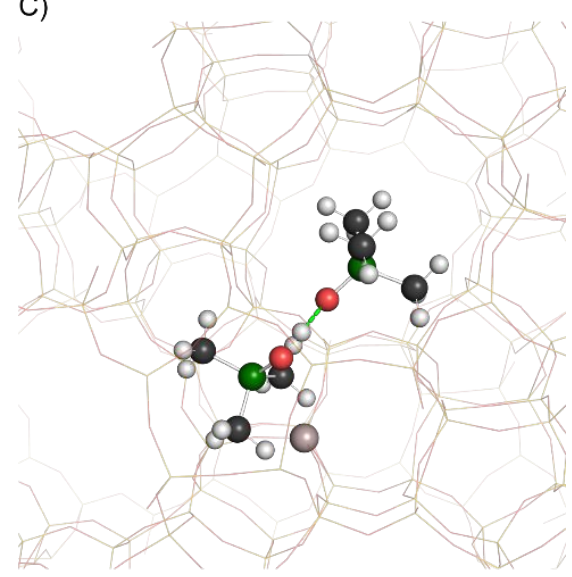

D)

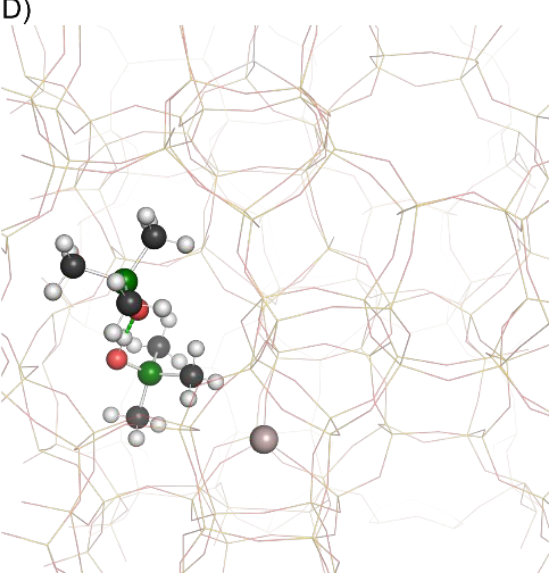

Figure S6. HZSM-5 zeolite framework viewed along the crystallographic b-axis (A and C) and a-axis (B and D). DFT (A, B) and AIMD followed DFT (C, D) geometry optimized TMPO:Brønsted acid 2:1 models at the $10 \mathrm{MR}$ sinusoidal channels showing a (TMPO) ${ }_{2} \mathrm{H}^{+}$ion forming between the 10MR channel and the channel intersection. Calculated ${ }^{1} \mathrm{H}$ and ${ }^{31} \mathrm{P}$ chemical shifts and interatomic distances are given in Table S10.

Table S1. Relative intensities (\%) obtained from the deconvolution of the ${ }^{31} \mathrm{P}$ MAS NMR spectra of HZSM-5 samples loaded with different amounts of TMPO.

\begin{tabular}{|c|c|c|c|c|c|c|c|c|c|}
\hline \multirow{2}{*}{ Samples } & \multicolumn{9}{|c|}{${ }^{31} \mathrm{P}$ resonances $(\mathrm{ppm})$} \\
\hline & 87 & 85 & 76 & 69 & 64 & 50 & 43 & 36 & 32 \\
\hline MFI-1mg & 1.0 & 6.9 & 19.2 & 44.0 & 12.0 & 14.1 & 0.9 & - & 1.1 \\
\hline MFI-2mg & 1.5 & 3.1 & 11.9 & 15.8 & 26.1 & 33.7 & 4.0 & 1.6 & 2.3 \\
\hline MFI-4mg & - & 1.1 & 10.5 & 13.3 & 31.6 & 38.3 & 4.8 & 2.9 & 2.1 \\
\hline
\end{tabular}

Table S2. Relevant calculated and experimental ${ }^{1} \mathrm{H}$ and ${ }^{31} \mathrm{P}$ chemical shifts and calculated adsorption ( $\left.\mathrm{E}_{\text {ads }}\right)$ energy for TMPO at the distinct acid site siting.

\begin{tabular}{|c|c|c|c|c|c|c|}
\hline TMPO:Brønsted & Site & $\mathrm{E}_{\mathrm{ads}}\left(\mathrm{kJ} \mathrm{mol}^{-1}\right)$ & $\delta_{\mathrm{P}}^{\exp }$ & $\delta_{\mathrm{P}}^{\text {calc }}$ & $\delta_{\mathrm{H}}^{\exp }$ & $\delta_{\mathrm{H}}^{\text {calc }}$ \\
\hline \multirow{4}{*}{$\stackrel{\check{ت}}{ت}$} & 10MR sinusoidal & -125.125 & 64 & 63.4 & 15.5 & 14.4 \\
\hline & 10MR straight & -141.917 & 69 & 66.2 & 14.6 & 14.7 \\
\hline & Intersection & -236.697 & 77 & 77.5 & 12.6 & 12.5 \\
\hline & $\begin{array}{c}\text { Pure Si } \\
\text { intersection }\end{array}$ & -212.857 & 87 & 85.8 & 7.7 & 8.07 \\
\hline$\stackrel{\vec{N}}{\ddot{N}}$ & Intersection & -151.124 & $60 ; 49$ & $51.2 ; 45.20$ & $14.8-16.1$ & 15.4 \\
\hline
\end{tabular}


Table S3. Calculated energies, distances and chemical shifts for the system 2 TMPO molecules at the channel intersection containing 1 Brønsted acid site. $\mathrm{O}_{\mathrm{Z}}-\mathrm{H}$ is the distance from the acid proton to the zeolite framework. $\mathrm{O}_{\mathrm{P} 1}-\mathrm{H}$ and $\mathrm{O}_{\mathrm{P} 2}-\mathrm{H}$ are the distances between the acid proton and the first and second TMPO oxygen atoms, respectively. Calculated ${ }^{1} \mathrm{H}$ and ${ }^{31} \mathrm{P}$ chemical shifts are quoted in ppm and the energies in $\mathrm{kJ} \cdot \mathrm{mol}^{-1}$.

\begin{tabular}{cccccccc}
\hline Method & $\begin{array}{c}\text { Energy } \\
\left(\mathrm{kJ} \cdot \mathrm{mol}^{-1}\right)\end{array}$ & $\begin{array}{c}\mathrm{O}_{\mathrm{Z}}-\mathrm{H} \\
(\AA)\end{array}$ & $\begin{array}{c}\mathrm{O}_{\mathrm{P} 1}-\mathrm{H} \\
(\AA)\end{array}$ & $\begin{array}{c}\delta_{\mathrm{P} 1} \\
(\mathrm{ppm})\end{array}$ & $\begin{array}{c}\mathrm{O}_{\mathrm{P} 2} \cdots \mathrm{H} \\
(\AA)\end{array}$ & $\begin{array}{c}\delta_{\mathrm{P} 2} \\
(\mathrm{ppm})\end{array}$ & $\begin{array}{c}\delta_{\mathrm{H}} \\
(\mathrm{ppm})\end{array}$ \\
\hline DFT & $-1.846981 \mathrm{E}+07$ & 1.49 & 1.05 & 75.82 & 3.88 & 22.44 & 14.06 \\
AIMD & - & 3.89 & 1.04 & 59.80 & 1.34 & 51.93 & 16.35 \\
AIMD + DFT & $-1.846977 \mathrm{E}+07$ & 4.19 & 1.08 & 51.23 & 1.39 & 45.20 & 15.43 \\
\hline
\end{tabular}

Table S4. Calculated energies, distances and chemical shifts for the system 2 TMPO molecules at the pure silica channel intersection. $\mathrm{O}_{\mathrm{P} 1}-\mathrm{H}$ and $\mathrm{O}_{\mathrm{P} 2}-\mathrm{H}$ are the distances between the acid proton and the first and second TMPO oxygen atoms, respectively. Calculated ${ }^{1} \mathrm{H}$ and ${ }^{31} \mathrm{P}$ chemical shifts are quoted in $\mathrm{ppm}$ and the energies in $\mathrm{kJ} \cdot \mathrm{mol}^{-1}$.

\begin{tabular}{ccccccc}
\hline Method & $\begin{array}{c}\text { Energy } \\
\left(\mathrm{kJ} \cdot \mathrm{mol}^{-1}\right)\end{array}$ & $\begin{array}{c}\mathrm{O}_{\mathrm{P} 1}-\mathrm{H} \\
(\AA)\end{array}$ & $\begin{array}{c}\delta_{\mathrm{P} 1} \\
(\mathrm{ppm})\end{array}$ & $\begin{array}{c}\mathrm{O}_{\mathrm{P} 2} \cdots \mathrm{H} \\
(\AA)\end{array}$ & $\begin{array}{c}\delta_{\mathrm{P} 2} \\
(\mathrm{ppm})\end{array}$ & $\begin{array}{c}\delta_{\mathrm{H}} \\
(\mathrm{ppm})\end{array}$ \\
\hline DFT & $-1.846980 \mathrm{E}+07$ & 1.13 & 60.26 & 1.30 & 37.31 & 17.67 \\
AIMD & - & 1.14 & 71.90 & 1.50 & 62.25 & 15.27 \\
AIMD + DFT & $-1.846974 \mathrm{E}+07$ & 1.15 & 57.70 & 1.25 & 53.36 & 16.88 \\
\hline
\end{tabular}

Table S5. Calculated energies, distances and chemical shifts for the system 1 TMPO molecule siting at the channel intersection containing 1 Brønsted acid site. $\mathrm{O}_{\mathrm{Z}}-\mathrm{H}$ is the distance from the acid proton to the zeolite framework. $\mathrm{O}_{\mathrm{P} 1}-\mathrm{H}$ and $\mathrm{O}_{\mathrm{P} 2}-\mathrm{H}$ are the distances between the acid proton and the first and second TMPO oxygen atoms, respectively. Calculated ${ }^{1} \mathrm{H}$ and ${ }^{31} \mathrm{P}$ chemical shifts are quoted in $\mathrm{ppm}$ and the energies in $\mathrm{kJ} \cdot \mathrm{mol}^{-1}$.

\begin{tabular}{cccccc}
\hline Method & $\begin{array}{c}\text { Energy } \\
\left(\mathrm{kJ} \cdot \mathrm{mol}^{-1}\right)\end{array}$ & $\begin{array}{c}\mathrm{O}_{\mathrm{Z}}-\mathrm{H} \\
(\AA)\end{array}$ & $\begin{array}{c}\mathrm{O}_{\mathrm{P}}-\mathrm{H} \\
(\AA)\end{array}$ & $\begin{array}{c}\delta_{\mathrm{P}} \\
(\mathrm{ppm})\end{array}$ & $\begin{array}{c}\delta_{\mathrm{H}} \\
(\mathrm{ppm})\end{array}$ \\
\hline DFT & $-1.835132 \mathrm{E}+07$ & 1.56 & 1.05 & 77.5 & 12.5 \\
AIMD & - & 2.60 & 0.98 & 109.7 & 5.25 \\
AIMD + DFT & $-1.835129 \mathrm{E}+07$ & 1.68 & 1.02 & 79.7 & 10.5 \\
\hline
\end{tabular}

Table S6. Calculated energies, distances and chemical shifts for the system 1 TMPO molecule at the 10MR straight channel containing 1 Brønsted acid site. $\mathrm{O}_{\mathrm{Z}}-\mathrm{H}$ is the distance from the acid proton to the zeolite framework. $\mathrm{O}_{\mathrm{P} 1}-\mathrm{H}$ and $\mathrm{O}_{\mathrm{P} 2}-\mathrm{H}$ are the distances between the acid proton and the first and second TMPO oxygen atoms, respectively. Calculated ${ }^{1} \mathrm{H}$ and ${ }^{31} \mathrm{P}$ chemical shifts are quoted in ppm and the energies in $\mathrm{kJ} \cdot \mathrm{mol}^{-1}$.

\begin{tabular}{cccccc}
\hline Method & $\begin{array}{c}\text { Energy } \\
\left(\mathrm{kJ} \cdot \mathrm{mol}^{-1}\right)\end{array}$ & $\begin{array}{c}\mathrm{O}_{\mathrm{Z}}-\mathrm{H} \\
(\AA)\end{array}$ & $\begin{array}{c}\mathrm{O}_{\mathrm{P}}-\mathrm{H} \\
(\AA)\end{array}$ & $\begin{array}{c}\delta_{\mathrm{P}} \\
(\mathrm{ppm})\end{array}$ & $\begin{array}{c}\delta_{\mathrm{H}} \\
(\mathrm{ppm})\end{array}$ \\
\hline DFT & $-1.835114 \mathrm{E}+07$ & 1.43 & 1.06 & 66.2 & 14.7 \\
AIMD & - & 1.78 & 1.03 & 76.3 & 10.8 \\
AIMD + DFT & $-1.835121 \mathrm{E}+07$ & 1.52 & 1.04 & 68.1 & 13.4 \\
\hline
\end{tabular}

Table S7. Calculated energies, distances and chemical shifts for the system 1 TMPO molecule at the $10 \mathrm{MR}$ sinusoidal channel. $\mathrm{O}_{\mathrm{Z}}-\mathrm{H}$ is the distance from the acid proton to the zeolite framework. $\mathrm{O}_{\mathrm{P} 1}-\mathrm{H}$ and $\mathrm{O}_{\mathrm{P} 2}-\mathrm{H}$ are the distances between the acid proton and the first and second TMPO oxygen atoms, respectively. Calculated ${ }^{1} \mathrm{H}$ and ${ }^{31} \mathrm{P}$ chemical shifts are quoted in ppm and the energies in $\mathrm{kJ} \cdot \mathrm{mol}^{-1}$. 


\begin{tabular}{cccccc}
\hline Method & $\begin{array}{c}\text { Energy } \\
\left(\mathrm{kJ} \cdot \mathrm{mol}^{-1}\right)\end{array}$ & $\begin{array}{c}\mathrm{O}_{\mathrm{Z}}-\mathrm{H} \\
(\AA)\end{array}$ & $\begin{array}{c}\mathrm{O}_{\mathrm{P}}-\mathrm{H} \\
(\AA)\end{array}$ & $\begin{array}{c}\delta_{\mathrm{P}} \\
(\mathrm{Apm})\end{array}$ & $\begin{array}{c}\delta_{\mathrm{H}} \\
(\mathrm{ppm})\end{array}$ \\
\hline DFT & $-1.8351056 \mathrm{E}+07$ & 1.49 & 1.04 & 63.9 & 14.14 \\
AIMD & - & 1.43 & 1.06 & 68.1 & 14.67 \\
AIMD + DFT & $-1.8351146 \mathrm{E}+07$ & 1.46 & 1.05 & 69.0 & 14.08 \\
\hline
\end{tabular}

Table S8. Calculated energies, distances and chemical shifts for the system 1 TMPO molecule at the pure silica channel intersection. $\mathrm{O}_{\mathrm{Z}}-\mathrm{H}$ is the distance from the acid proton to the zeolite framework. $\mathrm{O}_{\mathrm{P} 1}-\mathrm{H}$ and $\mathrm{O}_{\mathrm{P} 2}-\mathrm{H}$ are the distances between the acid proton and the first and second TMPO oxygen atoms, respectively. Calculated ${ }^{1} \mathrm{H}$ and ${ }^{31} \mathrm{P}$ chemical shifts are quoted in ppm and the energies in $\mathrm{kJ} \cdot \mathrm{mol}^{-1}$.

\begin{tabular}{ccccc}
\hline Method & $\begin{array}{c}\text { Energy } \\
\left(\mathrm{kJ} \cdot \mathrm{mol}^{-1}\right)\end{array}$ & $\begin{array}{c}\mathrm{O}_{\mathrm{P}}-\mathrm{H} \\
(\AA)\end{array}$ & $\begin{array}{c}\delta_{\mathrm{P}} \\
(\mathrm{ppm})\end{array}$ & $\begin{array}{c}\delta_{\mathrm{H}} \\
(\mathrm{ppm})\end{array}$ \\
\hline DFT & $-1.835129 \mathrm{E}+07$ & 0.998 & 85.8 & 8.07 \\
AIMD & - & 0.988 & 97.0 & 3.7 \\
AIMD + DFT & $-1.835124 \mathrm{E}+07$ & 0.991 & 89.4 & 6.7 \\
\hline
\end{tabular}

Table S9. Calculated energies, distances and chemical shifts for the system 2 TMPO molecules at 10-MR straight channels. $\mathrm{O}_{\mathrm{P} 1}$ - $\mathrm{H}$ and $\mathrm{O}_{\mathrm{P} 2}-\mathrm{H}$ are the distances between the acid proton and the first and second TMPO oxygen atoms, respectively. Calculated ${ }^{1} \mathrm{H}$ and ${ }^{31} \mathrm{P}$ chemical shifts are quoted in $\mathrm{ppm}$ and the energies in $\mathrm{kJ} \cdot \mathrm{mol}^{-1}$.

\begin{tabular}{cccccccc}
\hline Method & $\begin{array}{c}\text { Energy } \\
\left(\mathrm{kJ} \cdot \mathrm{mol}^{-1}\right)\end{array}$ & $\begin{array}{c}\mathrm{O}_{\mathrm{Z}}-\mathrm{H} \\
(\AA)\end{array}$ & $\begin{array}{c}\mathrm{O}_{\mathrm{P} 1}-\mathrm{H} \\
(\AA)\end{array}$ & $\begin{array}{c}\delta_{\mathrm{P} 1} \\
(\mathrm{ppm})\end{array}$ & $\begin{array}{c}\mathrm{O}_{\mathrm{P} 2} \cdots \mathrm{H} \\
(\AA)\end{array}$ & $\begin{array}{c}\delta_{\mathrm{P} 2} \\
(\mathrm{ppm})\end{array}$ & $\begin{array}{c}\delta_{\mathrm{H}} \\
(\mathrm{ppm})\end{array}$ \\
\hline DFT & $-1.846966 \mathrm{E}+07$ & 1.46 & 1.04 & 65.91 & 4.29 & 22.42 & 13.96 \\
AIMD & - & 5.96 & 0.97 & 91.37 & 9.19 & 32.93 & 4.60 \\
AIMD + DFT & $-1.846974 \mathrm{E}+07$ & 5.58 & 0.98 & 94.83 & 9.27 & 24.64 & 4.24 \\
\hline
\end{tabular}

Table S10. Calculated energies, distances and chemical shifts for the system 2 TMPO molecules at $10 \mathrm{MR}$ sinusoidal channels. $\mathrm{O}_{\mathrm{P} 1}-\mathrm{H}$ and $\mathrm{O}_{\mathrm{P} 2}-\mathrm{H}$ are the distances between the acid proton and the first and second TMPO oxygen atoms, respectively. Calculated ${ }^{1} \mathrm{H}$ and ${ }^{31} \mathrm{P}$ chemical shifts are quoted in $\mathrm{ppm}$ and the energies in $\mathrm{kJ} \cdot \mathrm{mol}^{-1}$.

\begin{tabular}{cccccccc}
\hline Method & $\begin{array}{c}\text { Energy } \\
\left(\mathrm{kJ} \cdot \mathrm{mol}^{-1}\right)\end{array}$ & $\begin{array}{c}\mathrm{O}_{\mathrm{Z}}-\mathrm{H} \\
(\AA)\end{array}$ & $\begin{array}{c}\mathrm{O}_{\mathrm{P} 1}-\mathrm{H} \\
(\AA)\end{array}$ & $\begin{array}{c}\delta_{\mathrm{P} 1} \\
(\mathrm{ppm})\end{array}$ & $\begin{array}{c}\mathrm{O}_{\mathrm{P} 2} \cdots \mathrm{H} \\
(\AA)\end{array}$ & $\begin{array}{c}\delta_{\mathrm{P} 2} \\
(\mathrm{ppm})\end{array}$ & $\begin{array}{c}\delta_{\mathrm{H}} \\
(\mathrm{ppm})\end{array}$ \\
\hline DFT & $-1.846955 \mathrm{E}+07$ & 3.82 & 1.02 & 79.77 & 1.71 & 36.58 & 9.29 \\
AIMD & - & 5.71 & 1.00 & 82.46 & 1.80 & 17.10 & 7.45 \\
AIMD + DFT & $-1.846973 \mathrm{E}+07$ & 6.29 & 1.07 & 68.79 & 1.43 & 40.54 & 14.56 \\
\hline
\end{tabular}




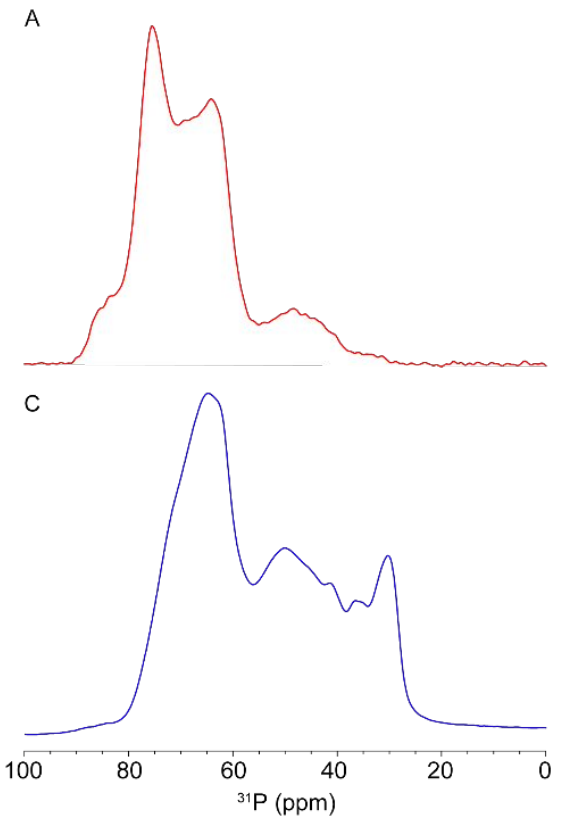

B

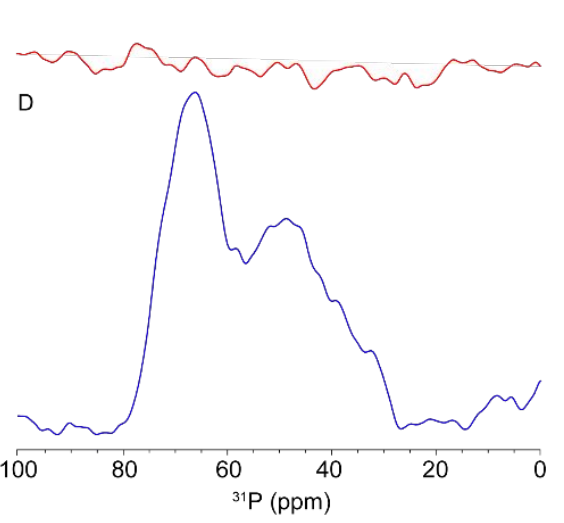

Figure S7. A and C) ${ }^{31} \mathrm{P}$ CPMAS and B, D) ${ }^{31} \mathrm{P}$ DQ-filtering spectra of HZSM-5 samples $\mathrm{P} / \mathrm{Al}=0.21$ loaded with $1 \mathrm{mg}(\mathrm{A}, \mathrm{B})$ sample $\mathrm{P} / \mathrm{Al}$ $=1.3$ loaded with $6 \mathrm{mg}(\mathrm{C}, \mathrm{D})$ of TMPO.

\section{REFERENCES}

(1) Bornes, C.; Amelse, J. A.; Peacock, M.; Marshall, C. L.; Schwartz, M. M.; Geraldes, C. F. G. C.; Rocha, J.; Mafra, L. Quantification of Brønsted Acid Sites in Zeolites by Water Desorption Thermogravimetry. European Journal of Inorganic Chemistry 2020, 2020 (19), 18601866. https://doi.org/10.1002/ejic.202000050.

(2) Massiot, D.; Fayon, F.; Capron, M.; King, I.; Le Calvé, S.; Alonso, B.; Durand, J. O.; Bujoli, B.; Gan, Z.; Hoatson, G. Modelling One- and Two-Dimensional Solid-State NMR Spectra. Magnetic Resonance in Chemistry 2002, 40 (1), 70-76. https://doi.org/10.1002/mrc.984.

(3) Database of Zeolite Structures http://www.iza-structure.org/databases/ (accessed Nov 13, 2020).

(4) Drout, R. J.; Kato, S.; Chen, H.; Son, F. A.; Otake, K.; Islamoglu, T.; Snurr, R. Q.; Farha, O. K. Isothermal Titration Calorimetry to Explore the Parameter Space of Organophosphorus Agrochemical Adsorption in MOFs. J. Am. Chem. Soc. 2020, 142 (28), $12357-12366$. https://doi.org/10.1021/jacs.0c04668.

(5) Dubbeldam, D.; Calero, S.; Ellis, D. E.; Snurr, R. Q. RASPA: Molecular Simulation Software for Adsorption and Diffusion in Flexible Nanoporous Materials. Molecular Simulation 2016, 42 (2), 81-101. https://doi.org/10.1080/08927022.2015.1010082.

(6) VandeVondele, J.; Krack, M.; Mohamed, F.; Parrinello, M.; Chassaing, T.; Hutter, J. Quickstep: Fast and Accurate Density Functional Calculations Using a Mixed Gaussian and Plane Waves Approach. Computer Physics Communications 2005, 167 (2), $103-128$. https://doi.org/10.1016/j.cpc.2004.12.014.

(7) Kühne, T. D.; Iannuzzi, M.; Del Ben, M.; Rybkin, V.V.; Seewald, P.; Stein, F.; Laino, T.; Khaliullin, R. Z.; Schütt, O.; Schiffmann, F.; Golze, D.; Wilhelm, J.; Chulkov, S.; Bani-Hashemian, M. H.; Weber, V.; Borstnik, U.; Taillefumier, M.; Jakobovits, A. S.; Lazzaro, A.; Pabst, H.; Müller, T.; Schade, R.; Guidon, M.; Andermatt, S.; Holmberg, N.; Schenter, G. K.; Hehn, A.; Bussy, A.; Belleflamme, F.; Tabacchi, G.; Glöß, A.; Lass, M.; Bethune, I.; Mundy, C. J.; Plessl, C.; Watkins, M.; VandeVondele, J.; Krack, M.; Hutter, J. CP2K: An Electronic Structure and Molecular Dynamics Software Package -- Quickstep: Efficient and Accurate Electronic Structure Calculations. 2020, 1-52.

(8) Perdew, J. P.; Burke, K.; Ernzerhof, M. Generalized Gradient Approximation Made Simple. Phys. Rev. Lett. 1996, 77 (18), 38653868. https://doi.org/10.1103/PhysRevLett.77.3865.

(9) Grimme, S.; Antony, J.; Ehrlich, S.; Krieg, H. A Consistent and Accurate Ab Initio Parametrization of Density Functional Dispersion Correction (DFT-D) for the 94 Elements H-Pu. The Journal of Chemical Physics 2010, 132 (15), 154104. https://doi.org/10.1063/1.3382344.

(10) Fischer, M.; Kim, W. J.; Badawi, M.; Lebègue, S. Benchmarking the Performance of Approximate van Der Waals Methods for the Structural and Energetic Properties of $\mathrm{SiO}_{2}$ and AlPO ${ }_{4}$ Frameworks. J. Chem. Phys. 2019, 150 (9), 094102. https://doi.org/10.1063/1.5085394.

(11) Fischer, M. Local Environment and Dynamic Behavior of Fluoride Anions in Silicogermanate Zeolites: A Computational Study of the AST Framework. J. Phys. Chem. C 2019, 123 (3), 1852-1865. https://doi.org/10.1021/acs.jpcc.8b10770.

(12) Fischer, M. Influence of Organic Structure-Directing Agents on Fluoride Dynamics in As-Synthesized Silicalite-1. J. Phys. Chem. C 2020, 12.

(13) Krack, M. Pseudopotentials for $\mathrm{H}$ to Kr Optimized for Gradient-Corrected Exchange-Correlation Functionals. Theor Chem Acc 2005, 114 (1-3), 145-152. https://doi.org/10.1007/s00214-005-0655-y.

(14) VandeVondele, J.; Hutter, J. Gaussian Basis Sets for Accurate Calculations on Molecular Systems in Gas and Condensed Phases. The Journal of Chemical Physics 2007, 127 (11), 114105. https://doi.org/10.1063/1.2770708.

(15) van Koningsveld, H.; van Bekkum, H.; Jansen, J. C. On the Location and Disorder of the Tetrapropylammonium (TPA) Ion in Zeolite ZSM-5 with Improved Framework Accuracy. Acta Crystallogr B Struct Sci 1987, 43 (2), 127-132. https://doi.org/10.1107/S0108768187098173. 
(16) Wolinski, K.; Hinton, J. F.; Pulay, P. Efficient Implementation of the Gauge-Independent Atomic Orbital Method for NMR Chemical Shift Calculations. Journal of the American Chemical Society 1990, 112 (23), 8251-8260. https://doi.org/10.1021/ja00179a005.

(17) Frisch, M. J.; Trucks, G. W.; Schlegel, H. B.; Scuseria, G. E.; Robb, M. A.; Cheeseman, J. R.; Scalmani, G.; Barone, V.; Petersson, G. A.; Nakatsuji, H.; Li, X.; Caricato, M.; Marenich, A. V.; Bloino, J.; Janesko, B. G.; Gomperts, R.; Mennucci, B.; Hratchian, H. P.; Ortiz, J. V.; Izmaylov, A. F.; Sonnenberg, J. L.; Williams; Ding, F.; Lipparini, F.; Egidi, F.; Goings, J.; Peng, B.; Petrone, A.; Henderson, T.; Ranasinghe, D.; Zakrzewski, V. G.; Gao, J.; Rega, N.; Zheng, G.; Liang, W.; Hada, M.; Ehara, M.; Toyota, K.; Fukuda, R.; Hasegawa, J.; Ishida, M.; Nakajima, T.; Honda, Y.; Kitao, O.; Nakai, H.; Vreven, T.; Throssell, K.; Montgomery Jr., J. A.; Peralta, J. E.; Ogliaro, F.; Bearpark, M. J.; Heyd, J. J.; Brothers, E. N.; Kudin, K. N.; Staroverov, V. N.; Keith, T. A.; Kobayashi, R.; Normand, J.; Raghavachari, K.; Rendell, A. P.; Burant, J. C.; Iyengar, S. S.; Tomasi, J.; Cossi, M.; Millam, J. M.; Klene, M.; Adamo, C.; Cammi, R.; Ochterski, J. W.; Martin, R. L.; Morokuma, K.; Farkas, O.; Foresman, J. B.; Fox, D. J. Gaussian 16 Rev. C.01; Wallingford, CT, 2016.

(18) Latypov, S. K.; Polyancev, F. M.; Yakhvarov, D. G.; Sinyashin, O. G. Quantum Chemical Calculations of 31 P NMR Chemical Shifts: Scopes and Limitations. Physical Chemistry Chemical Physics 2015, 17 (10), 6976-6987. https://doi.org/10.1039/C5CP00240K. 